\title{
"Very Good, I Shall Burn Her": The 1870 Torching of the Pirate Ship Forward and US-Mexican Relations
}

\section{James C. Knarr ${ }^{1}$}

Cet article s'adresse à l'incendie audacieuse en juin 1870 du vaisseau pirate Forward sur le fleuve mexicain Teacapan par les marins américains du USS Mohican, aux événements qui l'ont précédé, et à ses effets au Mexique et aux États-Unis. Le Mexique manquait les forces navales nécessaires pour parer aux déprédations du Forward, et le Mohican est immédiatement entré en action, sans sanction diplomatique, mais également sans toucher aux relations amicales entre les États-Unis et le Mexique. Ainsi l'incident éclaircit les relations amicales accumulées entre les États-Unis et le régime de Benito Juárez au Mexique pendant les années 1860, et également l'autoritarisme croissant de la marine américaine, dont les officiers ont commencé à se considérer policiers de l'hémisphère occidental.

On 17 June 1870, after forty miles and over twelve hours of exhausting oaring on the Teacapan River of western Mexico, the sixty-man expedition from the USS Mohican finally sighted their prize as the sun began to set: the pirate ship Forward. Led by Lieutenant Willard Brownson, USN, the sailors stealthily crept up on the vessel that had only the month prior ravaged the city of Guaymas, Mexico. Silently climbing on board, Brownson and some of the expedition's party found the ship largely abandoned before a round of shot roared at them like a clap of thunder from the coast, apparently from pirates who laid in wait on shore for the seamen. The sailors quickly threw themselves against the ship's bulwarks for safety. While still taking fire from the ambushing marauders, Brownson ordered his men to inspect the ship to see if she were moveable. Receiving intelligence that the Forward was in fact too hard aground to capture, he thus made the decision to scuttle her by emphatically declaring, "very good, I shall burn her." Still under fire, Brownson ordered his men to collect the ship's turpentine store and to ignite the Forward. While flame began to consume the piratical vessel, the lieutenant and his party bravely returned to their transports, eventually escaping to the safety of the

1 The author would like to thank the following historians for reading the manuscript and offering comments: Mary Knarr, Gene Smith, Claire Phelan, Larry Bartlett, Gary Ohls, Darren Plank, Jerry Pfabe, as well as Roger Sarty and the two anonymous reviewers at The Northern Mariner/Le marin du nord. He would also like to thank Susan Snyder at the University of California at Berkeley's Bancroft Library for assistance in obtaining the image of Plácido Vega as well as Dave Fiala for creating the maps on such a short timetable.

The Northern Mariner/le marin du nord, XXI No. 1, (January 2011), 27-45 
Mohican at river's mouth on the Pacific Ocean. ${ }^{2}$

Certainly the destruction of the pirate ship Forward in Mexican interior waters by seamen from the USS Mohican has not escaped the attention of historians but they examine the event too hastily. The first such account, in a study of the Mexican civil war in Sinaloa published only fourteen years after the event by Mexican historian Eustaquio Buelna, only mentions the initial piratical raid on Guayamas that catalyzed Brownson's action, not the efforts of the USS Mohican's men, and does so only in a paragraph. While later American historians have recognized the U.S. role in the event, they again treat the incident superficially. For example, Milton Offutt's 1928 study The Protection of Citizens Abroad by the Armed Forces of the United States and Harry Alanson Ellsworth's 1934 survey One Hundred Landings of the United States Marines, 1800-1934 each devote two pages to the incident, quickly reciting the events with little context. Clayton Barrow published a transcribed narrative of the capture of the Forward from Lieutenant Brownson in an edited volume America Spreads Her Sails (1973). This account, while thorough, tells only Brownson's side of the story. Finally, David Long's more recent Gold Braid and Foreign Relations: Diplomatic Activities of U.S. Naval Officers, 17981883 gives a bit more context but fails to detail many events in the one page he devotes to the episode. ${ }^{3}$

A more comprehensive examination of Forward's destruction is necessary for three reasons. First, Commander William Low of the USS Mohican took it upon himself, without orders from Washington, to destroy the buccaneer ship, revealing a sense of American authority in the hemisphere that was rare, though not unheard of in the nineteenth-century U.S. Navy. Second, unlike previous U.S. naval interventions against pirates, such as those of 1819 in the waters of Venezuela and Texas, and in the early 1820s off Cuba and Puerto Rico, the attack on the Forward occurred well within foreign territory. Starting in the early morning hours of 17 June 1870, Brownson's party pushed forty miles up the Teacapan River to accomplish its task of destroying the piratical craft. Third, in so doing, the officers and crew of the USS Mohican acted as the de facto naval

2 Clayton Barrow, ed., American Spreads Her Sails: U.S. Seapower in the $19^{\text {th }}$ Century (Annapolis, 1973), 139-150. The Río Teacapan, also known as the Rio de las Cañas, was much longer in 1870 than it is today owing to human and natural events. In 1870, the river's mouth (boca) was near the town of Teacapan, Sinaloa, after which the river went south before curving back north and, from there, heading east then southeast toward the Sierra Madre Occidental. All that remains from 1870 is the mouth of the river, the town of Teacapan, and the first mile or so inland. Nonetheless, its former course still forms the border between the states of Sinaloa to the immediate north and the canton of Tepic, since 1917 part of the state of Nayarit, to the immediate south.

3 To be fair, though, such through elucidation of the Forward incident was not these authors' purpose. See Eustaquio Buelna, Breves Apuntes para la Historia de la Guerra de Intervención en Sinaloa (Mazatlán, 1884), 22; Milton Offutt, The Protection of Citizens Abroad by the Armed Forces of the United States (Baltimore, 1928), 53-54; Harry Alanson Ellsworth, One Hundred Landings of the United States Marines, 1800-1934 (Washington, 1934), 114-15; David Long, Gold Braid and Foreign Relations: Diplomatic Activities of U.S. Naval Officers, 1798-1883 (Annapolis, 1988), 344-345; Barrow, 138-152. 
authority of Mexico instead of acting solely for the interests of the United States. This diplomatic context has been most conspicuously absent from previous studies of the incident, which generally infer that Low had some high-level Mexican authority when, in fact, he did not. The Forward's sensational demise represents an important event in American diplomatic and naval development. Naval officers, acting without orders from Washington, engaged a pirate ship in a friendly nation's inland waters, enhancing the U.S. Navy's prestige and amity between liberals in the two North American republics.

The Forward incident traced its beginnings to the 1864-67 civil war in Mexico. During this conflict, Benito Juárez and his liberal allies, with at least nominal support of most Western governments, had fought a guerrilla war against the French-supported Emperor Maximilian, using as their base the city of El Paseo del Norte (presently Ciudad Juárez in the state of Chihuahua). By 1867, increasing Prussian power in Europe caused French Emperor Napoleon III to recall his troops supporting Maximilian's regime and the puppet government quickly crumbled. Ultimately, Maximilian and his two most prominent conservative Mexican allies, Miguel Miramón and Tomás Mejía, met their deaths outside Querétaro, ending the civil war and restoring Juárez to power on 19 June 1867.

During the conflict, Washington materially and politically supported the liberal Juárez regime despite the obvious handicap of fighting its own civil war against the Southern Confederacy. Materially, the United States provided weaponry and medicine to the Juárista cause. With adept political and financial supervision from the Mexican minister to the United States, Matías Romero, various U.S. and Mexican citizens were able to purchase and to ship rifles, ammunition, gunpowder, and surgical supplies to the Juáristas. Politically, given the exigencies of a concurrent civil war in the United States, the Abraham Lincoln administration could offer no more than non-recognition of Maximilian's regime in Mexico City to aid Juárez until 1865. The effective destruction of the Confederacy in April of that year enabled U.S. diplomatic support to assume more than a token character. For example, in July 1866, President Andrew Johnson sent General William Tecumseh Sherman to Veracruz to support Juárez but the war hero could not find the Mexican president. At the same time, Johnson ordered prominent cavalry commander Phillip Sheridan to lead a large army to Texas ostensibly to maintain order and to reconstruct the wayward state. While there, Sheridan covertly aided the Juárista armies on the south side of the border by supplying them "with arms and ammunition, which [Sheridan's army] left at convenient places on [the U.S.] side of the border to fall into [Juárista] hands," and, furthermore, disseminated rumors that his force "was to cross the Rio Grande in behalf of the Liberal cause." Therefore, by the time of Maximilian's death in 1867 , the liberals under Juárez had a very positive relationship with Washington and for the next nine years, U.S.-Mexican friendship arguably peaked. ${ }^{4}$

$4 \quad$ Robert Ryal Miller, "Arms across the Border: United States Aid to Juárez during the French Intervention in Mexico," Transactions of the American Philosophical Society, New Series, LXIII, no. 6 (1973), 1-68; Robert Ryal Miller, "Matías Romero: Mexican Minister to the United States during the Juárez-Maximilian Era," The Hispanic American Historical Review XLV, no. 2 (May, 1965), 228-245; Phillip H. Sheridan, Personal Memoirs of Phillip H. Sheridan, vol. 2 (New York, 1888), 215-16. A thorough investigation of ideological accord 
Nonetheless, the return of Juárez to Mexico City in 1867 did not bring peace and prosperity to Mexico. The inability of the central government to repair quickly the countryside from the ravages of the recent guerrilla conflict, and attempts by Juárez to centralize the government, against the tenets of Mexican liberalism, caused many antiJuárez uprisings by disenchanted liberals. One historian estimates that thirteen such local rebellions occurred between 1867 and $1870 .^{5}$

Certainly, such localism pervaded Mexican history in the nineteenth century and was not unique to the 1860 s and early 1870 s. Since at least independence in 1821, political instability bred localism, resulting in small patrias chicas (small homelands) throughout the country. The rugged men who ran these territories, caudillos, enhanced their wealth and power through forceful protection of their landed interests with armies loyal to them and occasionally on sea using hired marine mercenaries. These efforts aimed at resisting the centralization of the caudillo's lands by the national government and thus protecting his power. ${ }^{6}$

One such example of political localism after Juárez's return, the one which would catalyze the intervention of the USS Mohican, occurred in the Pacific-coast state of Sinaloa and was led by Plácido Vega, a former Juárista. Immediately before the French intervention, Vega had governed the state, but during the war against Maximilian he fled the country and worked on behalf of the Juárez government in San Francisco, California, successfully purchasing more than $\$ 600,000$ in arms for the Juárista cause before returning home in 1867 after the uprising against the Hapsburg emperor succeeded. Shortly afterwards, Vega's discontent

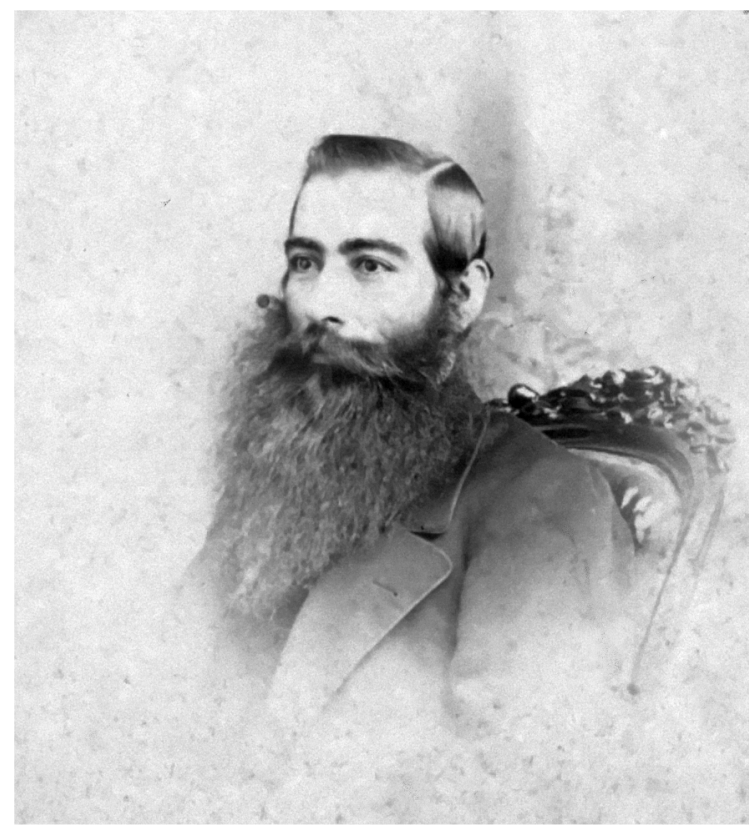

Illustration 1: Plácido Vega. Courtesy of The Bancroft Library, University of California, Berkeley. Call number: Vega, Plácido--POR 1.

between Juáristas in Mexico City and Republicans in Washington can be found in Thomas Schoonover, Dollars over Dominion: The Triumph of Liberalism in US-Mexican Relations, 1861-1867 (Baton Rouge, 1978).

5 Daniel Cosio Villegas, Historia Moderna de Mexico: La República Restorada, vol. I, La Vida Politica (Mexico City, 1955), 537-38.

6 Only after 1876, when Porfirio Díaz centralized his regime while allowing for some localism using political chiefs or jefes políticos, did calls for political localism abate. Nonetheless, localism as an ideology did not completely disappear. Indeed, historians such as Alan Knight have argued that this localism remained around in Mexico as the pervasive force that helped topple Díaz's regime in 1911. See Alan Knight, The Mexican Revolution (Cambridge, 1986). 
with Mexico City ostensibly over issues of political centralization became evident. In a proclamation on 8 February 1870 at Encarnación, Sinaloa, Vega stated his opposition to the "usurping President Juárez." Vega acceded in principle to the Plan of Zacatecas, a different statement of rebellion against the central regime from the adjacent state of Zacatecas. He asked "the legislature and executive or the state to sustain him," militarily and warned that if they refused, he would "assume the civil authority with extraordinary powers" and raise an army himself. When the Juárista administration in Sinaloa obviously refused to sanction Vega's actions, he built a private army around the mouth of the Teacapan River, which at the time was the border between the states of Sinaloa and Jalisco. Vega also received the protection of the caudillo Manuel Lozada, a powerful local leader with whom the Juárez government had agreed to a truce. For nominal recognition of Juárez's presidency, Lozada had received a pledge from Mexico City that government troops would not invade Lozada's territory. This arrangement permitted Lozada to create a virtual fiefdom in Jalisco and provided Vega with a secure base of operations. $^{7}$

To supply his rebel army, Vega began a systematic campaign of coastal piracy and interior raids, according to U.S. diplomats in Mexico who kept themselves apprised of the chaotic state of affairs that Vega's forays caused in Sinaloa. For example, the American consul at Mazatlán, Isaac Sisson, remarked on 4 March 1870 - less than a month after Vegas's rebellious announcement - that he found the state of Sinaloa in a "deplorable condition." The Juárista governor had fled to the mountains to raise his own army, leading Sisson to lament that "Sinaloa was never in as bad a condition." To compound the problems, the consul reported, "Vega is coming up from Jalisco, the state south of this, to proclaim himself Governor of this State."

On 29 March, the U.S. minister in Mexico City, Thomas Nelson, informed Washington that Vega's expedition to Tepic, a canton in western Jalisco, "completely failed" and that Tepic "would soon be secure against invaders." By early April, the tables had turned: "the vanguard of [Juárista] Col. Parra's command was defeated by a rebel force under Plácido Vega . . . at a point in Sinaloa about a hundred miles from Mazatlán, and at the latest advices Vega was advancing toward" the important coastal port. The tide again changed and in early May Nelson reported that the entire rebellion "has resulted in complete failure and that [Vega's] troops have been dispersed"; this coupled with incorrect news "that the intrepid bandit died recently at Tepic," greatly encouraged Nelson. ${ }^{9}$

7 Walter V. Scholes, Mexican Politics during the Juárez Regime, 1855-1872 (Columbia: University of Missouri Press, 1957), 110; Robert Ryal Miller, "Plácido Vega: A Mexican Secret Agent in the United States," The Americas XIX, no. 2 (October 1962): 137; "Plan of Plácido Vega" reprinted from El Diario Oficial (Mexico City), 10 March 1870, translated and enclosed in Thomas Nelson to Hamilton Fish, 24 March 1870, Department of State, Diplomatic Dispatches, Mexico, Microcopy M97, roll 40, RG 59, National Archives and Records Administration (hereafter NARA); Isaac Sisson to Nelson, 13 June 1870, enclosed in Nelson to Fish, 10 July 1870, ibid., roll 41.

8 Sisson to Nelson, 4 March 1870, enclosed in Nelson to Fish, 24 March 1870, ibid., roll 40.

9 Nelson to Fish, 29 March 1870, Nelson to Fish, 3 April 1870, Nelson to Fish, 10 May 1870, 
Meanwhile, Alexander Willard, U.S. Consul in Guaymas, Sonora, warned that Vega was planning a new offensive. "[T]here is . . . a faction in this state that await only the success of the revolutionary movement of General Vega in the states of Sinaloa and Jalisco to develop into a political party," Willard reported on 31 March 1870 . That faction would thereafter "declare themselves in his favor under the pretext of saving this country 'from the iniquitous compact' which President Juárez (so they report) is about to make with the United States, to despoil and rob Mexico of her territory." Willard reported that Vega "must first demonstrate that he has the means at his command and the ability as a soldier . . . before the state of Sonora will render to his movement any tangible assistance." Given that Vega's inland campaigns had failed - as Nelson reported - it was not surprising that the rebel began to focus on coastal raids to curry support in the state of Sonora. What Vega did not realize was that his actions would ultimately lead to the involvement of the United States Navy. ${ }^{10}$

By the middle of May 1870, American officials suspected that Vega planned to move beyond the area of Tepic, where the Mexican army kept his forces in check and his supplies limited, and embark upon a maritime expedition. In Mexico City, Nelson received information from Tepic that the citizens of that town planned "to extricate themselves from the difficulties occasioned by Plácido Vega" and that Vega aimed to "attack the State of Sinaloa at another point, perhaps in the neighborhood of El Fuerte," a city a few miles inland in northern Sinaloa, near the Sonoran border. Given the overland distance to El Fuerte, Nelson's anonymous purveyor of intelligence astutely expected a maritime expedition, noting that Vega had "a steamer and a sailing vessel at his disposal, but his force is small, and it seems his only hope is that his friends [at El Fuerte] may render him some assistance." 11

The steamer Forward originally sailed under the British flag, until San Francisco merchant James Maule purchased the ship and registered it in San Salvador. He chartered it on 4 January 1870 to San Francisco merchant Charles Jansen and a few days later Forward left San Francisco for Mazatlán under the command of Captain James Jones on "a legitimate voyage" according to Jansen's later testimony. The charter agreement was for "the term of twelve months [for] fishing, trading, [and] freighting ... to and from ports or places on the coast of the Republic of Mexico, and . . p ports and places on the Pacific coast of the United States of America." On 24 March, the ship docked at Mazatlán, where the Juárista authorities, suspecting collusion with the Vega rebellion, detained it and its captain for three weeks, making sure to take "some of her machinery and a portion of her sails" ashore "to prevent her escape." The Juáristas found nothing to implicate the ship or its crew and allowed it to sail south to San Blas, where Jones received a permit to fish for oysters at the mouth of the nearby Teacapan River. ${ }^{12}$

ibid.

10 Alexander Willard to Fish, 31 March 1870, Department of State, Consular Dispatches, Guaymas, Mexico, Microcopy M284, roll 1, RG 59, NARA.

11 Nelson to Fish, 29 May 1870, Department of State, Diplomatic Dispatches, Mexico, Microcopy M97, roll 41, RG 59, NARA.

12 Ellsworth, 114; Willard to Nelson, 18 November 1870, Foreign Relations of the United 
There, in the center of Vega's power, the Forward became a pirate vessel after Juárista authorities arrested Captain Jones. Apparently, Captain Jones had anchored the ship at the mouth of the river for three days in late April when a local Juárista military officer Jesus Vega, of no relation to Plácido Vega, ordered the Forward into port. Jesus Vega arrested the American captain, arguing that Jones took "cannon on board at San Blas and landed them at Boca Teacapan for Plácido Vega." Jones posted a three-thousand dollar bond and remained free in Mazatlán while awaiting trial. Meanwhile the steamer suddenly left port for an unknown destination and became a pirate ship. ${ }^{13}$

Since the ship engaged in piracy after its sudden captain-less departure, Jones's arrest helps clarify who among the various parties involved, Jesus Vega, the captain, and the crew, may have colluded with the rebels, facts of vital importance after the burning of the Forward. Because Jesus Vega turned Jones over to authorities in Mazatlán, a Juárista stronghold, one can assume that he was a firm Juárista acting on what he believed to be correct intelligence as to the ship's mission. The validity of the intelligence, of course, remains in doubt.

Captain Jones's role is less clear. While Jones protested his March 1870 detention in Mazatlán "one, twice, thrice, and as many times as may be necessary," this does not prove or disprove his complicity in the plot. Quite possibly, the second arrest by Jesus Vega in April thwarted Jones in joining with the rebels. Alternatively, Jones may not have intended to participate in the plot and in that case Plácido Vega's men may have circulated false intelligence in order to have him removed from the Forward. Finally, Jones may have been oblivious to any plot and his arrest may have been a simple stroke of luck for the rebels. In any event, though the Mazatlán authorities viewed Jones "as a friend of Vega," they did not have the "proofs sufficient to make it clear" and the Mexican officials officially acquitted him of any wrong-doing and released him by November 1870. Historians, working with a different set of evidence, need not heed judicial determinations or assumed culpability. ${ }^{14}$

Circumstantial evidence strongly suggests that at least part of the original American crew engaged in the later piracy. First, the consul at Mazatlán wrote that the Forward had an "oar crew of Americans, Germans, and Mexicans." Second, when Lieutenant Brownson boarded the ship after its capture he noted that, among those taken prisoner, he "saw six men standing there, evidently not Mexicans" some of whom spoke colloquial English. Third, Consul Willard in Guaymas later noted that of these six captured, "two . . c claimed to be native-born citizens of the U.S. and three . . c claimed to have been naturalized." Fourth, the ship originally sailed from San Francisco, Vega's base

States (hereafter FRUS) 1870-1, 614; Charles Jansen to Willard, 21 July 1870, ibid., 615; "Charter of the Forward" enclosed in Nelson to Fish, 29 September 1870, Department of State, Diplomatic Dispatches, Mexico, Microcopy M97, roll 42, RG 59, NARA; Sisson to Nelson, 4 June 1870, in Nelson to Fish, 30 June 1870, ibid., roll 41.

13 Sisson to Nelson, 4 June 1870, in Nelson to Fish, 30 June 1870, ibid.

14 James Jones to the Citizen Governor of the State of Sinaola, 28 March 1870, enclosed in Nelson to Fish, 29 September 1870, ibid. roll 42; Willard to Nelson, 18 November 1870, FRUS 1870-1, 614. 
during the fight against Maximilian. This body of evidence does not preclude that new Americans joined the expedition at some point, replacing the original San Francisco crew. Evidence that at least one member of the original crew was in the piratical party arose only after the capture of part of the Forward's crew with evidence from Jansen that he employed one of the six prisoners taken in the raid, George Holder. That fact would play a very important role in determining who later assumed blame for the May 1870 raid on Guaymas. ${ }^{15}$

What is beyond dispute is that when the Forward next appeared, at Guaymas on 28 May 1870, she was under the command of the rebel Vega's forces. It was the vessel's actions at Guaymas that prompted the United States Navy to act as an agent of a foreign power.

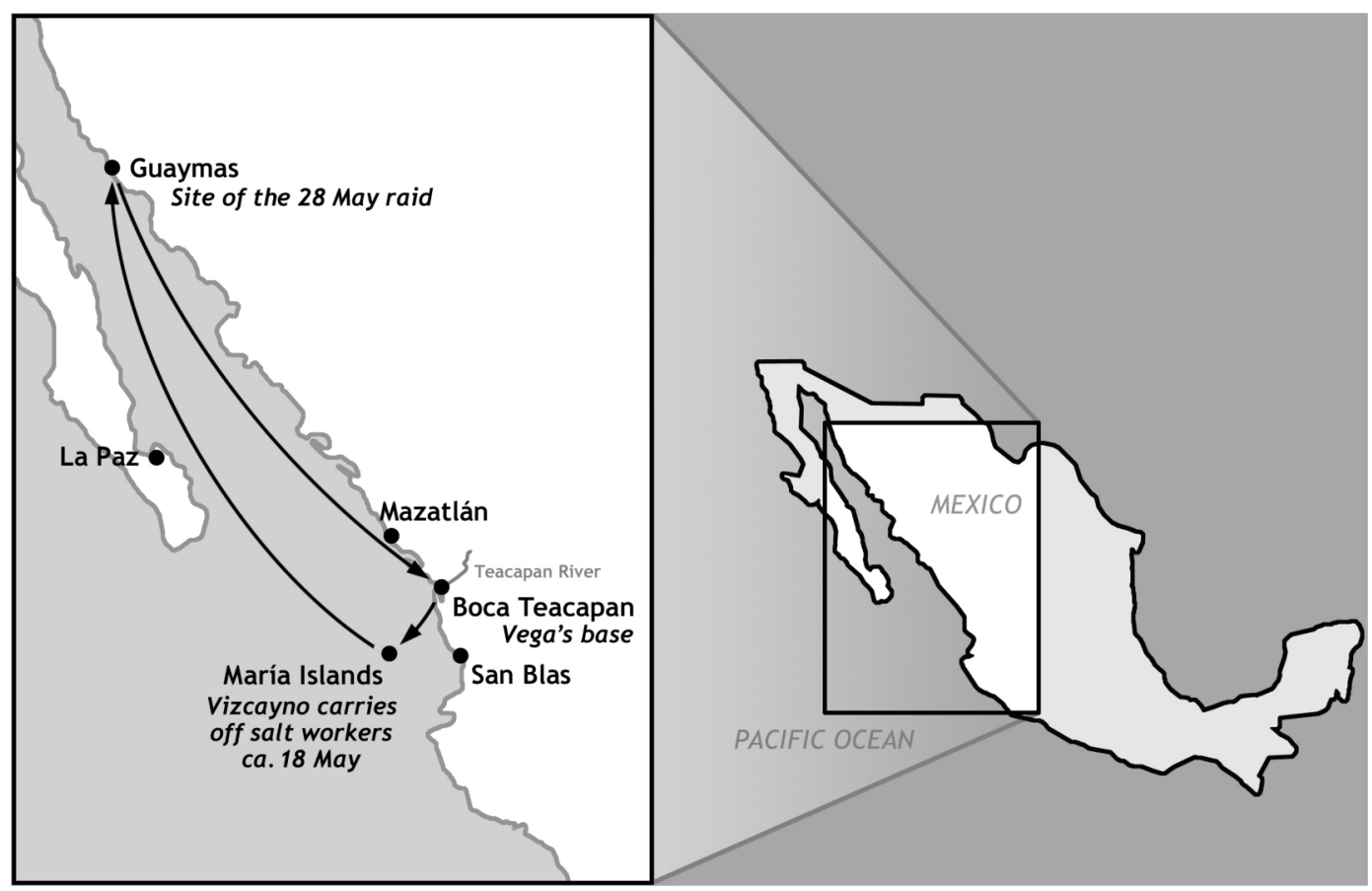

Illustration 2: The Path of the Forward under the command of Fortino Vizcayno, starting at Boca Teacapan (May 1870). Map by Dave Fiala.

Plácido Vega clearly ordered the raid on Guaymas in late May 1870, about a month after the Forward's first detention in Mazatlán. In written instructions dated 18 May 1870 from the mouth of the Teacapan River, which Vega later sent to Mexican newspapers and Nelson forwarded to Washington, the rebel leader gave his subordinate

15 Jansen to Willard, 21 July 1870, ibid., 615; "Charter of the Forward" enclosed in Nelson to Fish, 29 September 1870, Department of State, Diplomatic Dispatches, Mexico, Microcopy M97, roll 42, RG 59, NARA; Sisson to Nelson, undated, enclosed in Nelson to Fish, 30 June 1870, ibid. roll 41; Barrow, 144; Willard to John Chandler Bancroft Davis, 24 June 1870, Department of State, Consular Dispatches, Guaymas, Mexico, Microcopy M284, roll 1, RG 59, NARA; Willard to Davis, 1 July 1870, ibid. 
Fortino Vizcayno a very specific plan of attack against the coastal town. Calling himself the "Commander in Chief" of the "Division of Sinaloa," Vega ordered Vizcayno to accomplish four specific tasks and to complete them with "the well known good conduct of the force under your command." First, after coming ashore, Vizcayno should obtain "two hundred and eight cases, containing five thousand Prussian rifles" sent to him from San Francisco aboard the American schooner Montana but which the "arbitrary" Juárez government forbid Vega to collect from the customs house. Second, Vizcayno should "impose without fail a forced loan of four hundred thousand dollars" from the local merchant houses and to obtain "corresponding receipts . . . signed by the Paymaster Citizen Ignacio Carreau." Third, Vega ordered Vizcayno to conscript "the greatest number of men possible." Finally, "if the circumstances of [the] expedition permit it," Vizcayno should attempt to "land at the port of La Paz (Baja California) ... [and] impose a loan of thirty thousand dollars." 16

Vizcayno did not delay and left the mouth of the San Pedro River aboard the Forward soon after these instructions. He "touched at the islands of Maria," off the coast of Jalisco, where his men "carried off the workmen who were employed by Don C. Villaseñor" in the salt mines. He continued north thereafter. ${ }^{17}$

Once arriving at Guaymas, Vizcayno followed dutifully Vega's instructions and carried out other acts of piracy. On the evening of 27 May 1870, fishermen reported the Forward six miles offshore from the Sonoran port. At 3 am on 28 May, an expeditionary party led by Vizcayno "entered the city taking it by surprise, without opposition, taking on board the collector of customs and his officers and the Jefe de Hacienda Lic[enciado] Alfonso Mejía, and almost all of the local authorities," according to the U.S. consul. Immediately, Vizcayno's party forced loans from the local merchants, collected only approximately $\$ 42,000$ from the house of Ortiz Hermanos, obtained receipts for this money from the kidnapped customs collector, and "seized two Mexican vessels laying in port." Afterwards, the party requisitioned the five thousand muskets, which U.S. Consul Willard reported were "brought [to Guaymas] originally for the Mexican government, but not accepted." Later in the day, the Forward itself came into port and Vizcayno requisitioned "some fifty odd tons of coal, the property of the California line of steamers," telling Willard that "urgent necessity compelled the seizure, but [Vizcayno] would pay $\$ 40.00$ per ton, double the market value," for the fuel. The following morning, 29 May, Vizcayno paid for the coal. Upon seeing government troops entering the city at $3 \mathrm{pm}$, Vizcayno's crew prepared for its departure, "evidently wishing to avoid an attack ... a as all of the money due the Customs House from the merchants had been collected." They embarked at $8 \mathrm{pm}$ with the two seized vessels and government forces retook the city two hours later. ${ }^{18}$

16 Plácido Vega to Fortino Vizcayno, 18 May 1870, enclosed in Nelson to Fish, 10 July 1870, Department of State, Diplomatic Dispatches, Mexico, Microcopy M97, roll 41, RG 59, NARA.

17 "El Estado de Colima," 16 June 1870, enclosed in Nelson to Fish, 10 July 1870, ibid.

18 Willard to Nelson, 1 June 1870, enclosed in enclosed in Nelson to Fish, 6 July 1870, ibid.; Willard to Fish, 15 July 1870, Department of State, Consular Dispatches, Guaymas, Mexico, Microcopy M284, roll 1, RG 59, NARA. 
The human cost of the raid was relatively minor. According to the Mexican military commander that chased the Forward from Guaymas, one Mexican soldier had suffered injuries because of the raid and "we have to lament one death on our part in the said engagement." Another anonymous source reported "several deaths" without elaborating. Moreover, the pirates kidnapped a number of people during the raid, though two prisoners escaped as the Forward prepared to disembark and the pirate crew released the remainder but for Alfonso Mejía, Guaymas customs collector and son of Juárez's secretary of war and marine. This abduction occurred despite the "urgent solicitation" of Willard, who received assurances from Vizcayno that "no fears need to be entertained for [Mejía's] life." 19

The property losses at Guaymas were more extensive. A comprehensive list of losses compiled on 13 June 1870 by the American consul at Mazatlán found that "English, American, and Germans are the victims" of the robbery. Ortiz Hermanos calculated a total of $\$ 42,308$ in goods stolen from their warehouse, $\$ 12,985$ belonging to the English firm Rogers, Meyer, and Company based in San Francisco, $\$ 435$ belonging to the English firm J. Kelly and Company of Mazatlán, \$27,930 belonging to the German houses of Melchors Successor of Mazatlán and T. Heymann of Mazatlán, and finally, $\$ 958$ in goods from three Mexican firms. ${ }^{20}$

The Forward left Guaymas with Mejía aboard and headed south, never completing the optional mission of raiding $\mathrm{La} \mathrm{Paz}$ in Baja California. In fact, Willard reported the rumor that the Forward was going south to San Blas to join with Vega's forces to take Mazatlán, and somewhat prophetically noted that, "General Vega and his Western Republic are still in the balance and probably the next three months will decide its fate. ${ }^{21}$

Despite the threat that the U.S. consul believed the Forward posed to the Mexican republic, the Juárez regime's lack of capable naval forces seriously hindered its efforts to punish Vega. The Mexican general-in-chief in charge of the region, Bibiano Dávalos, thus articulated a solution in a letter to Consul Sisson at Mazatlán. "[I]t is the absolute duty of the naval forces to protect [the population]," wrote Dávalos, "but unfortunately, my government does not possess any." In view of the fact that "the United

19 Willard to Nelson, 1 June 1870, enclosed in enclosed in Nelson to Fish, 6 July 1870, Department of State, Diplomatic Dispatches, Mexico, Microcopy M97, roll 41, RG 59, NARA; "El Estado de Colima," 16 June 1870, enclosed in Nelson to Fish, 10 July 1870, ibid.; J. Garcia Morales to Ignacio Mejía, 30 May 1870, enclosed in Nelson to Fish, 10 July 1870, ibid.; Bibiano Dávalos to Sisson, 6 June 1870, enclosed in Nelson to Fish, 10 July 1870, ibid. Mejía, incidentally, escaped without injury in August 1870, after five anonymous men overpowered his guards and freed him. See Willard to Davis, 1 Sept 1870, Department of State, Consular Dispatches, Guaymas, Mexico, Microcopy M284, roll 1, RG 59, NARA. "Statement to the losses sustained at Guaymas," enclosed in Nelson to Fish, 10 July 1870, Department of State, Diplomatic Dispatches, Mexico, Microcopy M97, roll 41, RG 59, NARA.

21 Willard to Fish, 15 July 1870, Department of State, Consular Dispatches, Guaymas, Mexico, Microcopy M284, roll 1, RG 59, NARA. 
States man-of-war Mohican is at the present in these waters," he asked Sisson to "exert [his] influence with the commander of that ship, so that he may contribute to the apprehension of those criminals, who are doubtless near this coast, as they have two sailing vessels in tow." Later that month the government newspaper the Diario Oficial used this communication to claim that Sisson "ordered the steam man-of-war Mohigan [sic] to set sail in pursuit of the pirates," on the advice of Dávalos. Of course, such an order could not and did not come from Sisson. No order, in fact, ever came to the Mohican from any American official. ${ }^{22}$

The same day that Dávalos sent this request to Sisson in Mazatlán, Commander William Low's USS Mohican entered Guaymas for supplies and there Low first heard with disgust the results of the Vega raid on the city. He reported his intentions emphatically - to the Navy Department. Arguing that the Forward "was acting as a vessel of war, without the proper commission [from San Salvador] to act," and that "she was fitted out on the pretence of being engaged in acts of civil war, but in reality for the purpose of robbery," Low "deemed it [his] imperative duty to regard her as a piratical craft, and, in the assurance of the security of navigation, equally [his] duty to pursue, and, if possible, to capture or destroy her." Months later, Commodore William Taylor, commanding the North Squadron of the Pacific Fleet, added that Low also suspected the pirates would continue south to attack "one of the Panama steamers, and perhaps the Continental, which runs between Guaymas, Mazatlán, and San Francisco," though neither Low nor any other American naval officer offered corroborating written evidence for this suspicion. ${ }^{23}$

Low immediately left Guaymas and steamed after the Forward, but rather circuitously as it turned out. The Mohican first touched at Altata to the south two days later on faulty intelligence that the pirate ship went there. The American warship then departed for La Paz, Baja California. Not finding the Forward at that port, Low took on coal and, on 11 June, left for Ceralbo Island in the Gulf of California. Low next anchored at Mazatlán on 14 June, where he met with Consul Sisson and Mexican authorities, receiving their requests to act. Using language that indicated a higher purpose than simply aiding Mexican authorities, Low stated that while at this city he "received additional information confirmatory of my opinion that the Forward was a piratical craft under the law of nations, and that I should be derelict in my duty not to make every effort to take her." 24

22 Bibiano Dávalos to Sisson, 6 June 1870, enclosed in Nelson to Fish, 10 July 1870, Department of State, Diplomatic Dispatches, Mexico, Microcopy M97, roll 41, RG 59, NARA; "Guaymas - Piratical invasion," Semi-Monthly Review of the Diario Official (Mexico City), 29 June 1870, enclosed in Nelson to Fish 1 July 1870, ibid.

23 William Low to George Robeson, 19 June 1870, enclosed in "Report of the Secretary of the Navy," in House Exec. Doc. 1, 41 Cong., 3 sess., serial 1448, 144; William Taylor to Robeson, 12 July 1870, ibid., 142.

24 Low was not the only one to view the Forward as a pirate. For example, fifty years after the incidents described here Brownson recalled that upon hearing about the depredations of the Forward at Guaymas he felt that "this was nothing more or less than piracy according to all authorities and international law, and [the Forward] was liable to seizure by any nation in 


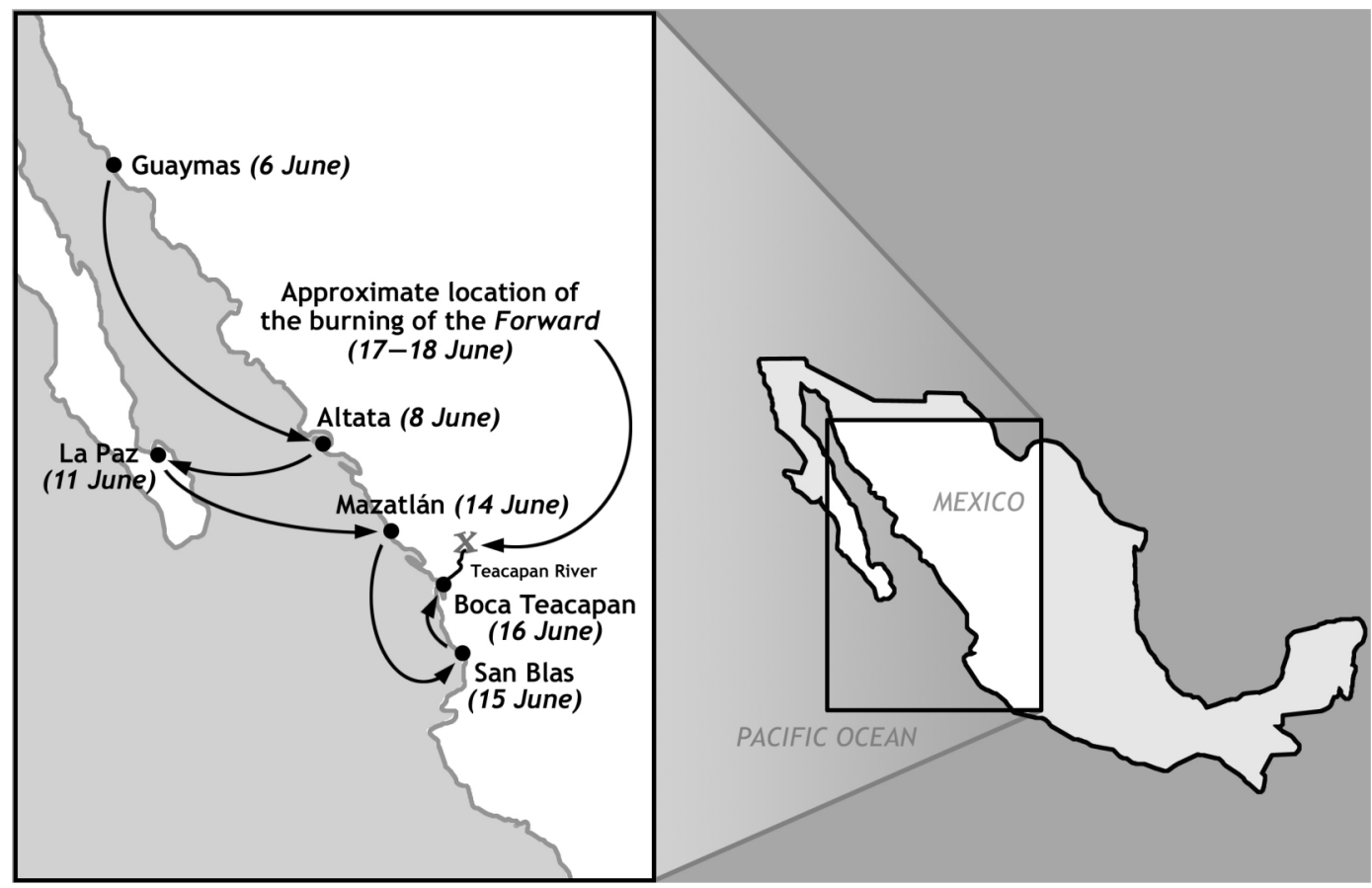

Illustration 3: The USS Mohican's Pursuit of the Forward, starting at Guaymas (June 1870). Map by Dave Fiala.

Why did Low so determinedly characterize the Forward as a pirate ship? While the definition of piracy then as now is fluid - one man's pirate is another man's highseas freedom fighter, after all - doubtlessly Low's recent experience during the Civil War (1861-1865) influenced his reaction to the Forward's raid on Guaymas. Low was well aware of one of the Navy's principal duties during that conflict: the pursuit and destruction of Confederate commerce raiders such as the CSS Alabama. In fact, Low had personal experience with this mission; between 1862 and 1863, he commanded the USS Constellation of the Mediterranean Squadron and pursued these raiders. Thus, in 1870 Low would have found parallels between the Alabama and the Forward, both being ships of an unrecognized rebellion engaging in raiding, though the Forward perpetrated her piracy on land rather than on water. Not surprisingly, Low's 1870 response to the Forward echoed that of Captain John Winslow of the USS Kearsarge in the pursuit of the CSS Alabama in 1864: to capture or to destroy the raider. ${ }^{25}$

any waters." Barrow, 139; Low to Robeson, 19 June 1870, enclosed in "Report of the Secretary of the Navy," in House Exec. Doc. 1, 41 Cong., 3 sess., serial 1448, 145.

The best overview of the Civil War at sea is Spencer C. Tucker, A Short History of the Civil War at Sea (Wilmington, 2002). For a specific discussion of the CSS Alabama and its commerce-raiding efforts, see Charles M. Robinson III, Shark of the Confederacy: The Story of the CSS Alabama (Annapolis, 1995). For his services in the Mediterranean, the Navy commissioned Low as a Lieutenant Commander in July 1862. In 1863, he took command of the gunboat USS Octorara, which served on blockade duty in the Gulf of Mexico until the end of the war. For a complete record of Low's career before the Forward burning, see 
Even so, Low still used local Juárista officials to justify his pursuit of the Forward to his superiors. A later report from Commodore Taylor stated that "Commander Low decided upon his course of action after free conference with Governor Rubi, of the state of Sinaloa, General Darlus [sic], commanding the forces in that state, and himself; and that the attack was made at the request of those authorities." In an even later report, Taylor added "Señor Supulvida, collector of customs at Mazatlán" to this group. $^{26}$

Even with the diplomatic cover these local officials gave Low, his decisiveness remained atypical for a ship commander on the Pacific Station in the 1870s. Often, Pacific Station commanders would only "proceed with caution, trying to decide the case on its merits ... [knowing] his conduct might become the subject of official inquiry," according to historian Robert Erwin Johnson. In Low's case, requests by Mexican and American diplomatic officials gave him confidence to track down and to destroy the pirate ship with little fear of protests from Mexico and censure by his superiors. ${ }^{27}$

Low took the Mohican in pursuit of the Forward from Mazatlán, this time with correct intelligence that the pirate ship had anchored somewhere to the south of the city. After sailing for about 140 miles, the Mohican put in at San Blas and received word that the Forward sat at the mouth of the Teacapan River, about 75 miles back north. Low steamed north, arriving on 16 June. Finding the mouth not navigable with his deep-draft ship, Low then devised a plan for a brown-water expedition under his second-incommand, Lieutenant Brownson. ${ }^{28}$

Low ordered Brownson to take upstream "all the boats of the ship, with the exception of the dinghy" and engage the Forward. Ideally, Brownson should "endeavor to take possession of her and bring her down to the bar in readiness when the tide serves," permitting him to "use the howitzer when within good range of the steamer to intimidate the crew" and take the ship. Low also provided a contingency plan if the pirates defended the Forward too effectively - he ordered Brownson simply to return to the Mohican. Finally, Low concluded with some practical advice, to "spare the men all unnecessary exposure to the sun" after the Forward's capture. ${ }^{29}$

Thus, starting at 2 am on 17 June 1870, Brownson led an expedition of "six boats and about 60 men in all" in search of the Forward at some point inland. Even before entering the river, the expedition encountered danger. Brownson needed the expertise of a man "who had recently enlisted at Mazatlán" to find a channel through "the heaviest

Lewis Randolph Hamersly, The Records of Living Officers of the U.S. Navy and Marine Corps with a History of Naval Operations during the Rebellion of 1861-5 and a List of the Ships and Officers Participating in the Great Battles (Philadelphia, 1870), 101. House Exec. Doc. 1, 41 Cong., 3 sess., serial 1448, 142; Taylor to Thomas Turner, 15 July 1870, ibid., 143.

27 Robert Erwin Johnson, Thence Round Cape Horn: The Story of United States Naval Forces on Pacific Station, 1818-1923 (Annapolis, 1963), 13-14.

28 Barrow, 141.

29 Ibid., 141-42. 
surf [he] had ever been through," as he wrote some years later. Overcoming the surf, the six craft entered the river, and using intelligence gleaned from trustworthy children at the small native village of Teacapan, Brownson believed the Forward had passed through only three or four days before. Continuing upriver, a fisherman met the party at about 3 pm, "carrying a load of water melons; ... . [the sailors] went for the melons and also for information," as Brownson put it. The fisherman merchant informed the party that the Forward sat twelve miles upstream and offered his services in locating it, an offer Brownson willingly accepted. Although the fisherman incorrectly assessed the distance, the party found the ship slightly after sundown, after traveling "over 40 miles" from the river's mouth. ${ }^{30}$

The engagement did not play out as expected but Brownson's courage and quickthinking assured that the Forward would never sail the ocean again. As the party approached the steamer in two columns, a small boat attempted escape. Brownson ordered Ensign Jonathon Wainwright, commanding one of the expedition's six boats, to seize that vessel while the remainder of the Mohican's boats continued to the main prize. The Forward was "hard aground . . . drawing seven feet and having only five feet of water under her." Brownson ordered his men to board, and most of the party gained the quarterdeck and encountered six men, "evidently not Mexicans." After confirming with these men that this ship was indeed the Forward, Brownson took possession of the ship, "in the name of Captain Low, commanding the USS Mohican." While these men - later identified as the pilot, machinist, and some firefighters - acquiesced in English, "a carbine was fired from [Wainwright's] first cutter and almost simultaneously a volley of shell, canister, and musketry from shore raked the decks and side of the steamer." Thankfully for Brownson, the "high bulwarks forward protected greatly the Mohican's men." According to Low's later estimates, 170 men of the pirate crew waited in ambush in the forest ashore; Brownson later surmised that a sentry warned the crew of their coming while the American seamen navigated the surf at the mouth of the river. These pirates used "four 12-pounders" complemented by some sharpshooters. Nonetheless, Brownson held the deck for nearly forty minutes. While under fire, he ordered the wounded and the six prisoners moved to the boats and inspected the Forward in an effort to determine a course of action. Having already "come to the conclusion that it would be impossible, under the circumstances, to take the ship out as she was hard aground with the tide failing," Brownson needed an alternative plan. Sailors sent below returned to report that the ship had "little or no coal in her and [that] her engines were disabled." With this news, Brownson exclaimed to his men: "Very good. I shall burn her." Later, Brownson explained that "after losing a man and having five more wounded, one of them Wainwright, a very dear friend, [he] didn't feel in a very good humor." He directed a lieutenant "to make arrangements aft in the officer quarters." Thereafter, Brownson and a portion of his expeditionary party covered the sleeping chambers and fire room with turpentine from the Forward's signal kit, set the ship afire, and removed to their boats, finally reaching the Mohican at 2:30 pm on 18 June with the wounded and the prisoners. Recognizing the difficulty of capturing the pirates ashore and having in any case 
immobilized them by destroying their ship, Brownson felt the risk was too great to try to arrest them. He thus left them in the Mexican jungle as he worked his way back to the Mohican. ${ }^{31}$

The destruction of the Forward came at a significant human cost. The Mohican's surgeon, who accompanied the expedition up the Teacapan River, reported that eight men became casualties, two of them fatal: Coxswain James Donnell died at the scene and Ensign Wainwright died of his wounds aboard the Mohican the following day. This latter loss profoundly affected both Low, who claimed Wainwright had "promise of a career valuable to the service," and Rear Admiral Thomas Turner, commander of the Pacific Fleet, who "rarely [knew] a young officer of higher promise." Of the six others wounded, all later recovered. ${ }^{32}$

Low "delivered to Mexican authorities at Mazatlán" all the prisoners, including two Yankees, George W. Holder, "presumed to be mate," and F.W. Johnson, "presumed to be engineer." While Low noted that Brownson's party had found no papers on board the Forward, at least one of these men came from San Francisco. Charles Jansen, as the owner of the ship's charter, mentioned Holder by name later and found the mate "grossly culpable" and deserving of "little sympathy." This demonstrates, as noted previously, that at least some of the original American crew, if not all of it, joined with Vega. Nevertheless, the prisoners would not see their day in court; in January 1871 they escaped aboard the U.S. schooner Selma while en route to Guaymas to stand trial. ${ }^{33}$

Low composed his official report as he sailed back to Mazatlán. Interestingly, while taking full responsibility, he took particular care in defending his use of expensive steam running in the pursuit. Brownson's actions, he wrote, were "vindicated by the spirit of my orders and justified by the circumstances of the case; I must consequently give it my approval." He continued, "I trust my action in this emergency may meet with the approval of the Department [of the Navy], and that in the use of steam I may also be justified." $" 34$

Low had the support of his superior officer, the commander of the Pacific Fleet.

31 Ibid., 144-47; Taylor to Turner, 15 July 1870, enclosed in "Report of the Secretary of the Navy," in House Exec. Doc. 1, 41 Cong., 3 sess., serial 1448, 143; Low to Willard Brownson, 20 June 1870, ibid., 147; "Juan sin miedo" enclosed in Willard to Davis, 1 July 1870, Department of State, Consular Dispatches, Guaymas, Mexico, Microcopy M284, roll 1, RG 59, NARA.

32 F.L. Patten to Robeson, 19 June 1870, Letters Received by the Secretary of the Navy from Commanding Officers of Squadrons, Microcopy M89, roll 51, RG 45, NARA; Low to Robeson, 20 June 1870, enclosed in "Report of the Secretary of the Navy," in House Exec. Doc. 1, 41 Cong., 3 sess., serial 1448, 148; Turner to Robeson, 15 August 1870, ibid., 149; Taylor to Robeson, 12 July 1870 , ibid., 141.

33 Taylor to Turner, 15 July 1870, ibid., 143; Jansen to Willard, 21 July 1870, FRUS 1870-1, 615; Willard to William Hunter, 30 January 1871, Department of State, Consular Dispatches, Guaymas, Mexico, Microcopy M284, roll 1, RG 59, NARA.

34 Low to Robeson, 19 June 1870, enclosed in "Report of the Secretary of the Navy," in House Exec. Doc. 1, 41 Cong., 3 sess., serial 1448, 145-46. 
In August 1870, en route from Peru to San Francisco, Rear Admiral Turner heard of the actions of the Mohican. After stopping at San Blas and Mazatlán, Turner concluded that Low gave a "detailed authentic account" and he found "no need of [his] commenting upon" the operations. Regarding Brownson's expedition, Turner later noted that the lieutenant's "action on this occasion justified my [favorable] impressions" of him. ${ }^{35}$

In early September 1870 Rear Admiral Turner met with British Admiral Arthur Farquhar, Royal Navy, commander of all British warships in the Pacific. Farquhar revealed that the British also sought the Forward after the raid at Guaymas, owing to the depredation against British commerce at that port. It gave Turner much pride, and he relayed to Washington Farquhar's quip: "this is always the way with you American Navy officers; you are ahead of us when a ship-of-war is required to be on the spot." 36

After the destruction of the Forward, American policymakers attempted to sort out the culpability for the raid on Guaymas. Given the strong relationship between the United States and the Juárez government, State Department officials in Mexico remained ambivalent when it came to pressing blame even as their superiors in Washington pushed them to fault the Mexican authorities. A letter from Sisson to Nelson dated 4 June 1870 argued for disavowing Mexican culpability and in fact anticipated later American foreign policy. Though a consistent critic of Mexican lawlessness, Sisson declared that he did "not see in any evidence yet before [the United States of] any good ground for holding the Mexican government responsible for the depredation of the Forward." Rather, no single government deserved the entire fault for the expedition because the ship flew the San Salvadorian flag, it belonged "in fact" to a Mexican citizen, an American citizen chartered it in San Francisco, and it took Mexican rebels on board at a Mexican port. The Juarez regime, he wrote, "was under no obligation to anticipate or guard against" rebels who would abscond a foreign vessel and engage in piracy, though "in this case [Mexico] seems to have done what it could." The United States, he likewise argued, "atoned for [any negligence] by destroying the Forward at the cost of the lives of at least two gallant officers." Nevertheless, Sisson worried about the precedent that Mexico's "inability to protect foreigners within its jurisdiction will have," as foreign governments would use such impotence as an excuse to invade the Latin American nation. Foreshadowing the Roosevelt Corollary of 1904 to the Monroe Doctrine, Sisson argued that such threat "will compel us, as the next neighbor - who will not allow foreign powers to seek redress by military force - to take upon ourselves the onus of establishing just an efficient government in Mexico." Thus, while Sisson treated Mexico as an immature child, he saw "nothing ... to warrant international sedative action." 37

35 Turner to Robeson, 1 September 1870, Letters Received by the Secretary of the Navy from Commanding Officers of Squadrons, Microcopy M89, roll 51, RG 45, NARA; Turner to Robeson, 3 September 1870, enclosed in "Report of the Secretary of the Navy," in House Exec. Doc. 1, 41 Cong., 3 sess., serial 1448, 149.

36 Turner to Robeson, 3 September 1870, ibid., 149.

37 Sisson to Nelson, 4 June 1870, enclosed in Nelson to Fish, 30 June 1870, Department of State, Diplomatic Dispatches, Mexico, Microcopy M97, roll 41, RG 59, NARA. Emphasis in original. 
Willard in Guaymas reported in mid July 1870 that the pirates had not in fact harmed American property: "the goods carried away from the . . house of Ortiz Hermanos were principally consigned goods, mostly German and English, (none American or belonging to American commercial houses, that I am aware of)." The only possible exception to this was the house of Roger Meyer and Company of San Francisco, but Willard noted that "this house is looked upon in [San Francisco] as an English commercial house." 38

It appears Nelson largely accepted these arguments, not pressing the matter until Washington forced the issue. In a reply dated 4 August 1870 to Nelson's dispatch about the depredation in Guaymas, Acting Secretary of State John Davis advised Nelson to "ascertain the losses which citizens of the United States may have sustained in consequence of" the raid. He mentioned specifically that in Washington "the Mexican government is regarded as accountable for them and you will demand reparations from that government accordingly." 39

Nelson replied that the Juárez administration was not culpable for the raid. $\mathrm{He}$ noted that the Forward "was fitted out for the cruise at San Francisco[,] . . that she carried the flag of San Salvador without lawful right or authority, and it is said that her objects and destination were the subject of public comment before she sailed." Therefore, "she was regarded by both American and Mexican officials on the coast as a pirate, and finally was pursued and destroyed as a pirate by an American man of war." While urging Washington to "form a just conclusion," Nelson endeavored to "take the necessary measures to ascertain the amount of such loses" in preparation to placing a protest before the Mexican government. ${ }^{40}$

The response from Secretary of State Hamilton Fish, dated 16 November 1870, was firm. Finding the responsibility of the Mexican government "unquestionable," Secretary Fish noted that the Mexican government, "so long as it shall claim jurisdiction over that territory, must be held responsible for any injuries to citizens of the United States." Furthermore, "the Mexican government had willfully connived at a defiance of its authority in the canton of Tepic" in accepting the caudillo Manuel Lozada's hegemony in the region. Consequently, Fish ordered that Nelson, "in a courteous way, make known to the minister for foreign affairs our views on this subject."

Nelson continued his intransigence. On 23 January 1871, he forwarded to Washington a series of letters that demonstrated the limited damage to American persons or property and the lack of responsibility on the part of Mexico City. The most important of these enclosures came from Willard in Guaymas, in which the consul reported that although some of the property taken on 28 May 1870 belonged to the firm of Rodger

38 Willard to Fish, 15 July 1870, Department of State, Consular Dispatches, Guaymas, Mexico, Microcopy M284, roll 1, RG 59, NARA. Emphasis in original.

39 Davis to Nelson, 4 August 1870, Department of State, Diplomatic Instructions, Microcopy M77, roll 114, RG 59, NARA.

40 Nelson to Fish, 29 September 1870, Department of State, Diplomatic Dispatches, Mexico, Microcopy M97, roll 42, RG 59, NARA.

41 Fish to Nelson, 16 September 1870, FRUS 1870-1, 607. 
Meyer \& Company, occasionally rumored to be American, "nothing has been done through the medium of the consulate ... in presenting proofs of the nationality of the said firm," and thus he could not say for sure if the firm claimed U.S. government protection. Furthermore, Willard could offer "no information" as to whether the Forward left San Francisco with the intention to engage in piracy and he knew "absolutely nothing" with regard to the rumors of collusion between the Forward's captain and Vega. Other enclosures, one from the Mexican official in charge of the customs house after the capture of Mejía and another from Willard, demonstrated the lack of any connection between the pirates and the regime in Mexico City. Nelson hoped that these enclosures "will perhaps be sufficient to settle the questions as to whether the government of Mexico should be held liable for the damage inflicted by the Forward." Apparently, they did as Washington sent Nelson no further instructions on the matter. ${ }^{42}$

With the matter concluded, one should look at the event's effects in Mexico, on the Vega rebellion, and most importantly for the United States Navy. What consequences did the Forward incident have in Mexico? In the short term, pro-American sentiment among Juárez and his supporters ran especially high. Nelson reported on 10 July 1870 that the "government press universally and cordially endorse[d]" the actions of the American sloop. Nelson also reported to Washington that Mexicans celebrated the Fourth of July in 1870 - three weeks after the Forward's destruction — "as is usual, by a display of the National Flag on the palace and all the public buildings" while "in most, if not all the cities of the republic, the day was honored by some public demonstration" and Juárez and several congressmen called at the American embassy "as a mark of respect for the day." In Guaymas, the scene of the depredation, Willard reported that "the authorities, having expressed their satisfaction and approval . . . fully endorse Captain Low's conduct," while they expressed a general "friendly feeling . . . towards the United States" because of the burning, some even going so far as to "wish that in the future [American] ships of war may do the same in times of trouble." Meanwhile, in Mexico City, the need to rely on a foreign power for protection caused policymakers to advocate the creation of a coast guard. In his annual message to Congress in July 1870, Juárez wrote that "there will . . . be submitted a plan for the establishment of coast-guard vessels, the necessity for which is proved anew by the recent painful experience at Guaymas."43

For Plácido Vega, the incident obviously had much more negative results. In July 1870 Willard noted that Vega's "condition (by the burning of the Forward) is now reduced to the basis of positive support from General Lozada of money and men." By 31 December, despite the failure of the military expedition promised by the Mexican

42 Nelson to Fish, 23 January 1871, ibid., 613-15.

43 Nelson to Fish, 11 July 1870, Department of State, Diplomatic Dispatches, Mexico, Microcopy M97, roll 41, RG 59, NARA; "Message of President Juárez to the Mexican Congress, September 16, 1870" enclosed in Nelson to Fish, 20 September 1870, ibid., roll 42; Willard to Davis, 1 July 1870, Department of State, Consular Disptaches, Guaymas, Mexico, Microcopy M284, roll 1, RG 59, NARA; Willard to Fish, 5 July 1870, ibid.; Willard to Davis, 21 July 1870 , ibid. 
government to materialize, Willard reported that Vega had disbanded his forces. The rebel did maintain a small fiefdom and a small army, though. In 1872, Vega used this army and his personal connections to aid the revolt of Porfirio Díaz in the Tepic region. By 1876, Díaz, like Vega once a supporter of Benito Juárez, succeeded where Vega could not in 1870 and overthrew the central regime in Mexico City, establishing a dictatorship that only the most bloody and climactic revolution in Latin American history would bring down starting in $1910 .^{44}$

The Forward's destruction was arguably a high-point in U.S.-Mexican relations, one in which a U.S. naval officer anointed himself a policeman of the seas and, building on pre-existing diplomatic and ideological accord, acted as the de facto maritime agent of another state without the formalities of an alliance or the threat of international war. ${ }^{45}$ As John Schroeder shows, owing to slowness of communications, American naval officers often served as diplomats in the nineteenth century. Another scholar whose work bears on the incident, Thomas Schoonover, suggests that diplomatic affinity between the two states in the 1860s resulted from what he calls the "liberal Weltanschauung" of commercial expansion and free trade. Although both these authors end their narratives in the 1860s, Commander Low's and Lieutenant Brownson's actions on the Pacific coast of Mexico exemplify the intersection of these two important elements in relations between Mexico and the United States as late as June 1870.

44 Willard to Fish, 15 July 1870, ibid.; Willard to Hunter, 31 December 1870, ibid.; Cosio Villegas, 723.

45 See John Schroeder, Shaping a Maritime Empire: The Commercial and Diplomatic Role of the American Navy, 1829-1861 (Westport, CT, 1985); Schoonover, xvi. 


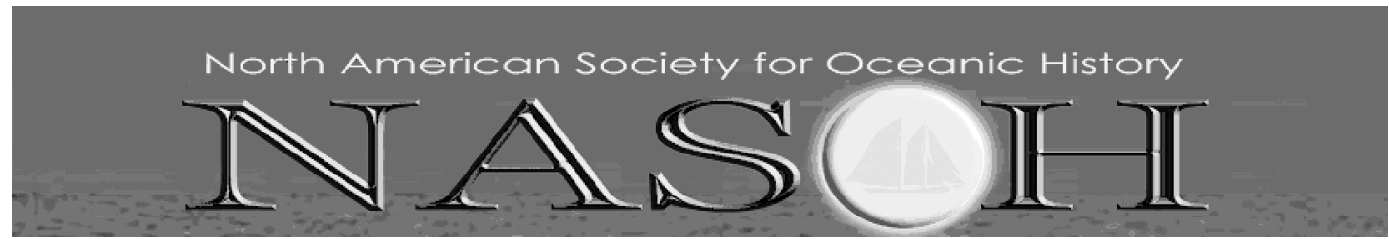

Annual NASOH conference 2011 at Old Dominion University in Norfolk, VA May $12^{\text {th }}-14^{\text {th }} / 1^{\text {th }} 2011$

MARITIME HISTORY RESEARCH AT THE BEGINNING OF THE 21ST CENTURY

\section{Call for Papers}

During recent decades maritime history has become far more diverse than ever before. New sub-disciplines of maritime history have developed, traditional topics have been examined from new perspectives, and inter-disciplinary research has become more a standard than an exception. National maritime history research has been embedded into international contexts and global cooperation is a standard for most maritime historians.

The annual NASOH conference 2011 to be hosted by Old Dominion University in Norfolk, VA aims to provide an overview on what is going on in maritime history at the beginning of the $21^{\text {st }}$ century. It aims to stimulate discussion on the development of the discipline as a whole in both a national and global context. Panels will address such questions as: To what degree have maritime historians understood the challenges of the $21^{\text {st }}$ century? In what ways can they contribute to the solution of global problems in the marine realm? What is the relationship of maritime history to new historical subdisciplines such as environmental or Atlantic-world history? Does traditional maritime history still make sense? What's the role of specialized museums and archives for future maritime history?

Proposals for panels of up to four speakers as well as proposals for individual papers addressing the state of the art of maritime history as well as new directions in maritime history research should be submitted prior Jan. $31^{\text {st }} 2011$ to the conference organizers via e-mail (iheidbri@odu.edu). Each proposal for a complete panel should include the title of the proposed session as well as a brief abstract of the session (200 words), the contact details for the organizer of the session and title, abstract (500 words) name and contact details for the individual papers of the proposed panel. Proposals for individual papers should include title, abstract (500 words) name and contact details. Please submit all proposals in one of the following file formats: pdf, doc or rtf (please no docx-files).

\author{
Dr. Ingo Heidbrink \\ Professor of History \\ -Graduate Program Director- \\ Dept. of History \\ 8046 Batten Arts and Letters Building \\ Old Dominion University \\ Norfolk, VA 23529
}

\author{
tel. $757-683-3656$ or -3949 \\ fax.757-683-5644 \\ email: iheidbri@odu.edu \\ Skype: ingo.heidbrink
}

